酸素とはどのような反応性を示すか検討した結果，谷易に重合物 を与えるとい5 Staudinger らの結果を再現し，さらにとの生成 する重合物の楧造を明らかにするとともに，分子量や重合の特性 について若干検討した。
本研究の内容の一部は日本化学会第 17 年会（昭和 39 年 4 月, 東京）にて講演した。おわりに本研究の赛験の一部を担当して頂 いた浪川茂夫氏括よび発表を許可された当社取楴役前研究所長德 江 豛博士，本研究所長潮四常三博士に謝意を表する。

\title{
無水ピロメリット酸と環状エーテルとの共重 合
}

(昭和 40 和 2 月 17 日受理)

\author{
多田紘一・至枝 武夫・古川淳二*
}

2 官能性の䱇水ピロメリット酸と 3 是環, または 4 員環エーテルとの共重合を希薄溶液中で行なうと, 重合系はダル化 せずに有機溶剂に可溶の共重合体が得られた。IR スペクトルでしらべると，酸無水物基が全部消費されており，また生 成物が可溶性であること扰よび氷点降下法，末端基定量法による分子量がほぼ一致したから，このるのの構造はべンゼン 核を橋かけにして，その両側で酸無水物と環状ェーテルとが交互共重合した“はしこ”状ポリマーであると推定した。た だ共重合体の組成は 3 員䍙エーテルとの組合せでは 3 員環エーテルの方が酸無水物基より多く入っでり，完全な“はし ごではなく、エーテルの連続した部分も存在し，部分的に“はしご”構造が乱れているよらであった。

\section{2 緒言}

2 它能性モノマーを 2 段階で重合させて“はしご状楥造をも

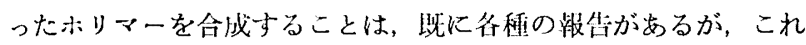
を1段の盘合反応で行なうことについては報告されていないよう

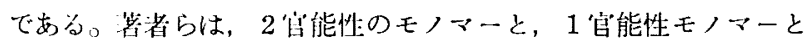
を, 倠溥浴液で其重吕させて 1 段階で“はしこ”状ボリーを得 ることを目的にここの搰を験をなった。

ここでとりあげた其重合文心は，酸無水物と塄状ェーテルとの

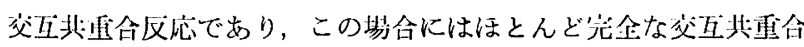
体ポリエステルが得られることはよく知られているところで女 $ろ^{1,2)}$ 。

著者らは，この共重合反心を 2 官能性無水物である無水ピロ人 リット酸 (PDA) に応用し，これと環状エーテルとを共重合やし めて，ベンゼン核の両侧に，エステル結合からなる 2 本の主鎖の 伸びた “はしご”状ポリマーの合成を試みた。

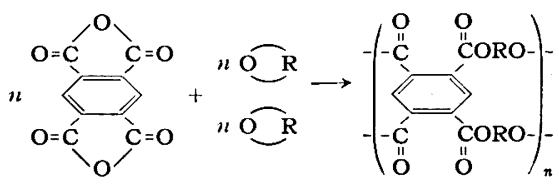

環状エーテルとしては，フェニルグリシジルェーテル (PGE), エピクロルヒドリン $(\mathrm{ECH})$, エチレンオキシド(EO), および 3 , 3-ビス(クロルメチル)オキセタン (BCMO) を用いた。重合溶媒 にはジオキサンを用い，触媒としては Fisher や Hamann らの 実験に従っていろいろ試みたが，3員㻴エーテルの場合には， $N, N^{\prime}$-ジメチルベンジルアミン (DMBA) が BCMO の場合には フタル酸ナトリウムや塩化リチウムが有効であった。

* Koichi Tada, Takeo Saegusa, Junji Furukawa 京

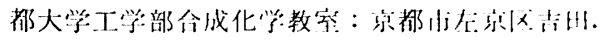

1) R. F. Fisher, J. Polymer. Sci. 44, 155 (1960).

2) Von E. Schwenk, K. Gulbins, M. Roth, G. Benzing, R. Maysenhölder, K. Hamann, Makromol. Chem. 51, 53 (1962).
希溥溶液での重合では, ゲル化ポリマーの生成はほとんどなく， 有機溶剤に可溶のポリマーが得られた。またこのポリマーのIR スペクトルから，カルボン酸や酸無水物に関する吸収は認められ ず,すべての酸無水物基はェステル結自にかわったものと思われ， ボリマーの構透としては，上Kホしたような“はしご”状の構造 になっているものと思われる。しかし，ホリマーの組成は 3 員環 エーテルとの共重合体では，爸互共重合体と考えた場合より多く のエーテルが会まれ，4員環エーテルでは逆に少ない。分子量が せまり人きくないので，本端のニニットの影響もあり，一方，同 じ条俳の下で 3 員環エーテルの単独重合が珰められたことから, 一部には土ーテルの連続した部分が存在するものと思われる（コ ポリマー小に結合しているのか，あるいはホモポリマーとして存 在するのかはわからない)。

\section{2 実 験 の 部}

\section{$2 \cdot 1$ 試 薬}

無水ピロハリット酸は, 朾眅品を酢酸エチル溶液から再結晶し たものを使用した。環状エーテル, 溶媒, 触媒はいずれも市販品 を通常のう法により精製した後使用した。

\section{$2 \cdot 2$ 重合方法}

窒素置換した $200 \mathrm{~m} l$ のすり合せガラス重合管に無水ピロメリ ット酸, 環状エーテル, ジオキサン, 触媒を入れて栓をし, $100^{\circ} \mathrm{C}$ に加熱, 静置重合した。重合温度が $150^{\circ} \mathrm{C}$ の場合にはすり合せ栓 は用いずに溶封した。また環状ェーテルとしてEOを用いる場合 には，還流冷却器をつけた丸成フラスコを用いてかくはんしなが らEOを吹込むか，あるいは通常の重合管に氷水を通した還流冷 歫器をつけて加熱還流した。

重合停止にはメタノールを加え，溶液を濃絔したうえで，む5 一度大量の人タノールを加えておとし，これを集めて乾燥した後 ジオキサンに䕐かし，不溶部を口別し，溶液は濨繀した後に，大 蜰のメタノールに投じてジオキサン川溶部とした。 


\section{3 結果と考察}

\subsection{PDA-PGE 共重合}

2官能性モノマーを含を系を通常の条件で重合させれば、 ラン ダムに橋かけしたポリマーとなり，系はゲル化するのが普通であ る。著者らが目的とした“はしこ”状ポリマーを得るためには， 少なくとも系のゲル化を防止するようにしなければならない。そ

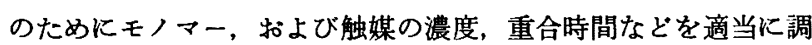
節しなければならないといらことは容易に想像される。以下に， PDA とPGE の共重合に括ける, これら三つの条件の影響と生 成物の組成，物性等について述べる。

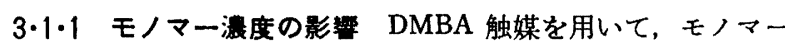
濃度をかえたときの実験結果を表 1 に示した。触蝶はPDA に対 していずれも 2 mol\%ずつ加えたために，系中の触媒量はいずれ も一定であり，したがって溶媒の量をかえるとモノマー濃度だけ でなく，触媒濃度もかわっていることになる。しかし次節で述べ るように，この程度の触媒濃度では系のゲル化には影響しないこ とがわかって扣り，実験結果はモノマー濃度のちがいによるとの み考えてもほとんど差支えないものと思う。

\section{表 1 PDA-PGE 共重合—モノマー濃度の影響—— 重合条件：PDA $0.007 \mathrm{~mol} ， P G E 0.070 \mathrm{~mol}$ DMBA 対 PDA $2 \mathrm{~mol} \%$, 重合温度 $110 \sim 120 \mathrm{C}$}

\begin{tabular}{|c|c|c|c|c|c|c|c|c|}
\hline 実匬番号 & $\begin{array}{l}\text { ジオキサン } \\
(\mathbf{m} l)\end{array}$ & $\begin{array}{l}\text { 首合時間 } \\
\text { (hr) }\end{array}$ & $\begin{array}{c}\text { 収 事 } \\
(\%)\end{array}$ & $\begin{array}{l}\text { ジクロルエ } \\
\text { タ岢溶部 } \\
(\%)\end{array}$ & $\begin{array}{c}\text { ジオキサン } \\
\text { 可 溶 部 } \\
(\%)\end{array}$ & 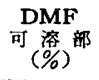 & $\begin{array}{c}\text { 可 浴部 } \\
\text { の會計 } \\
(\%)\end{array}$ & $\begin{array}{c}\text { 挢出残分 } \\
\text { (不溶部) } \\
(\%)\end{array}$ \\
\hline ST-147-1 & 20 & 15 & 109 & 7.2 & 7.8 & trace & 15.0 & 85.0 \\
\hline-2 & 50 & 15 & 103 & 18.8 & 4.9 & 0.3 & 24.0 & 76.0 \\
\hline-3 & 80 & 32 & 98 & 100 & 0 & 0 & 100 & 0 \\
\hline
\end{tabular}

モノマー濃度の高い場合に収率は 100\%を越えた。この点につ いては後に述べる。ST-147-1 では重合開始後, 数時間で完全に ゲル化し，また ST-147-2でも15 時間後にはゲル化したが, ST-147-3 では 32 時間後も系はほとんど均一で, ゲル化はみら れなかった。生成物をジクロルェタン, ジオキサン, DMF の順 で抽出したが，ST-147-1 㧊よび 2では抽出物に比し残分のうが ずっと多かったが, ST-147-3 ではほとんど 100\%がジクロルェ タンに可溶であり，モノマー濃度の系のゲル化に扣よぼす影響が 極めて大きいことがわかる。

ジクロルエタン可溶部はジオキサンに溶け，また DMF 可溶部 の量は非常に少なかった。更に DMF で抽出した残分は他の有機 溶剤にも溶けず, ランダムな橋かけしたものと思われるので, 以 後は生成物をジオキサンで分別して，可溶部と不溶部に分け，不 溶部をランダムに橋かけしたものとみなすことにする。可溶部は “はしこ” 状の構造をるつものと考えるが，この点については後 に述べる。

$3 \cdot 1 \cdot 2$ 触媒浱度の影彎 モノマーおよよ゙溶媒の量を一定にし $\tau$, 触媒 (DMBA) の量を PDA K対して 5 mol\% から 0.005 mol\% まで変化させたときの結果を表 2 に示した。

ここでしらべた範囲の触媒濃度では，たとえ最高の $5 \mathrm{~mol} \%$ の 触媒を用いても系はほとんどゲル化せず，生成ポリマーの全部が ジオキサンに可溶であり，不溶部は僅少にすぎなかった。したが って, 触媒濃度のぶル化におよぼす影響は, この程度の濃度範囲 では全くないとみて差支えない。

触媒量の少ない方が重合度はやや大きい。また高触媒濃度に拉
表 2 PDA-PGE 共重合——触媒淟度の影響——

重守尔件 : PDA $0.007 \mathrm{~mol} 、$ PGE $0.070 \mathrm{~mol}$ 、ジオキサン $80 \mathrm{ml}$ (ST-158 はこれの $1 / 2$ のスタール), 重合温度 $100 \mathrm{C}$ ，重合時間 $100 \mathrm{hr}$

\begin{tabular}{|c|c|c|c|}
\hline 灾検番岇 & 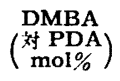 & $\begin{array}{c}\text { 収繁 } \\
(\%)\end{array}$ & 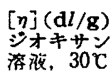 \\
\hline ST-158-1 & 5.0 & 86 & 0.030 \\
\hline-2 & 2.5 & 103 & 0.043 \\
\hline-3 & 1.3 & 110 & 0.037 \\
\hline-4 & 0.65 & 48 & 0.047 \\
\hline-5 & 0.32 & 57 & 0.040 \\
\hline ST-151-5 & 0.20 & 81 & 0.082 \\
\hline ST-154-1 & 0.10 & 27 & 0.058 \\
\hline-2 & 0.05 & 14 & 0.067 \\
\hline-3 & 0.01 & 6 & 0.084 \\
\hline-4 & 0.005 & 6 & 0.097 \\
\hline
\end{tabular}

いては，モノマー濃度の高い場合と同様に収浨は 100\%を越して いる。

$3 \cdot 1 \cdot 3$ 重合時間の影暗 重合時間の収率および 極限粘度に対 する影響をみたのが表 3である。

重合系はいずれも均一であり，得られたポリマーのほとんどす ベてがジオキサンに可溶で不溶部は蕉少にすぎなかった。

収率は重合時間の増加とともにほとんど直線的に増加するが, 生成ポリマーの極限粘度には, ほとんど 差が認められなかった。無水フタル酸と アリルグリシジルエーテルとの交互共重 合を DMBA 触媒で行な弓場合に，活性 末端の無水フタル酸モノマーへの連鎖移 動がかなり谷易であることが知られてい る1が, PDA-PGE 共重合の場合にも， やはりモノマーへの連鎖移動が大きいた

表 3 PDA-PGE 共重合一重合时間の影響——

重合条件: PDA $0.007 \mathrm{~mol}$, PGE $0.070 \mathrm{~mol}$. DMBA 对 PDA 0.2 $\mathrm{mol} \%$, ジオキサン $80 \mathrm{~m} l$, 重合温度 $100 \mathrm{C}$

\begin{tabular}{|c|c|c|c|}
\hline 尖野番号 & $\begin{array}{l}\text { 重合時間 } \\
(\mathrm{hr})\end{array}$ & $\begin{array}{l}\text { 収 婆 } \\
(\%)\end{array}$ & 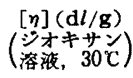 \\
\hline ST-151-1 & 20 & 13 & 0.057 \\
\hline-2 & 40 & 28 & 0.053 \\
\hline-3 & 60 & 40 & 0.056 \\
\hline-4 & 80 & 56 & 0.060 \\
\hline-5 & 100 & 81 & 0.082 \\
\hline-6 & 340 & $111\left\{\begin{array}{l}\text { ベンゼン可魰部 }(22 \%) \\
\|(78 \%)\end{array}\right.$ & $\begin{array}{l}0.050 \\
0.080\end{array}$ \\
\hline
\end{tabular}

めに極限粘度に差が出なかったものと思われる。重合時間を極め て長くした場合に収率が 100\%を越している点, およびこの試料 をべンゼンで分別した点については後述する。

3・1.4 PDA-PGE 共重合体の諸物性 DMBA 触媒により得 たポリマーについて，その性質をしらべた。

このポリマーがジクロルェタン，ジオキサンに可溶であること はすでに述べたが，そのほかにク口ロホルム，酢酸エチル， DMF，DMSO 等にも可溶である。溶解する前にいったん膨潤す る。ジクロルベンゼン, トリクロルベンゼンには不溶であった。 ポリマーを $300^{\circ} \mathrm{C}$ まで加熱したが， $250^{\circ} \mathrm{C}$ 位でやや軟化する だけで全く溶融しなかった。

X線的には全く非晶性であったが，これは後述するように， PDA とPGE が完全な 1:2 の組成の “はしご”状になってい ないこと, および $\mathrm{PGE}$ の $\mathrm{C}_{6} \mathrm{H}_{5} \mathrm{OCH}_{2}$ - 基が側鎖にあるためであ ろっ。 


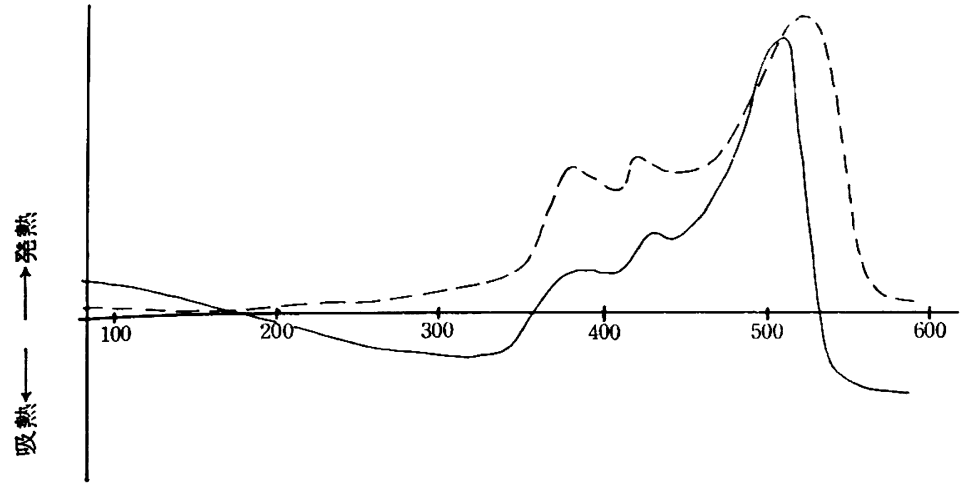

温度 ( $\left.{ }^{\circ} \mathrm{C}\right)$

为 1 PDA-PGE 共重合物の DTA 曲楾

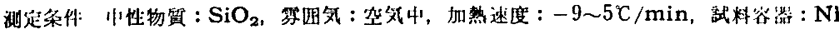

一：ジオキサン可溶部 (ST-151-5)

……: : シオキサン不溶部 $($ ST-147-1)

ポリマーを示差熱分析にかけたところ，図1に示したような DTA 曲線が得られた。ジオキサン可溶部も不溶部もほとんど同 じ曲線で室温から $580^{\circ} \mathrm{C}$ まで加熱する間に 3 本の発熱ピークがみ られた。これらのピークが，それぞれど5いう変化を示するのか は明確でないが，加熱後の試料の重量は加熱前の $10 \%$ 弱で黒色 の炭化物しか残っていなかったことから，これらの発熱ピークは 酸化分解 (燃焼) を意味するものだと思われる。曲線より，この 変化は $340^{\circ} \mathrm{C}$ 位からはじまる。な拈 $250^{\circ} \mathrm{C}$ 付近でのポリマーの 軟化に相当するような変化は，この DT $\Lambda$ 曲線では念められなか った。

3・1.5 PDA-PGE 共重合体の組成と構造 酸無水物とエホキキ シドとの共重合で得られるポリマーは，笔全に交互共重合したボ リエステルであることが知られているが1,2)，PDA-PGE 共重合 では，今までになん回も述べたように, 収率が理論量の 100\%を越 えた場合がしばしばあり，その原因の一つとして PDA と PGE と が完全な交互共重合をしていないで，部分的に PGE の連続した 部分があるのではないかと考光, 共重合体の組成怙よび構造につ いて IR スペクトル拈よびポリマーのケン化によってしらべだ。 またポリマーの分子量を氷点降下法および末端基定量法により測 定し比較検討した。

図 2 に共重合体（ジオキサン可溶部）の IR スペクトルを示し た。

$1710 \mathrm{~cm}^{-1}$ に $>\mathrm{C}=0$ 基, $1210 \mathrm{~cm}^{-1}$ にエステル基に基うく吸 収がみられ，その外に PDA ニニットに由来する四㯰換ベンゼン 核の吸収が $915,875 \mathrm{~cm}^{-1}$ に, PGE ユニットに由来するベンゼ ン核の吸収が $1590,1580,780,740 \mathrm{~cm}^{-1}$ に，またエーテル結合

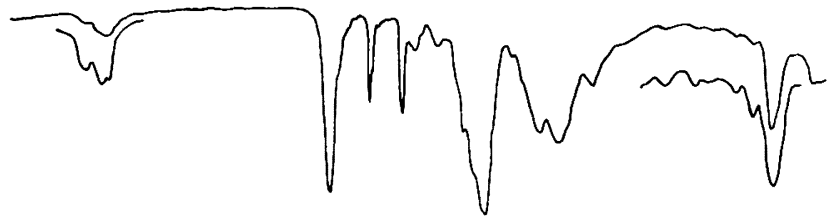

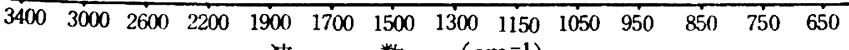
波 数 $\left(\mathrm{cm}^{-1}\right)$

図 2 PDA-PGE 共重合体（ジオキサン可溶部）の赤外吸収スペクトル
の吸収が 1115 と $1080 \mathrm{~cm}^{-1}$ に文られる。酸無水物基の $>\mathrm{C}=\mathrm{O}$ 基は，1860, $1760 \mathrm{~cm}^{-1} k \mathrm{COOH}$ 基は 3500 , 1700 1680，1440１395 $\mathrm{cm}^{-1}$ に出るはずだが，これら に相当する吸収はみられなかった。すなわち，PDA の 二つの酸無水物基は、ほとんどすべてがェステル結合に かわっているものと思われる。一方，PGE が開環して 連続した部分のェーテル結合は，側鎖のエーテル結合と 吸収が重なるため，IR スペクトルからだけでは PGE の連続した部分があるかどうかは判定できない。

そこで共重合体の組成をポリマーのケン化により， ア ルカリの消費量から求めた。結果は表 4 に示した。

表 4 の右端に示した共重合体中の PGE と PDA との モル比はいずれも2 より大きい。本報告の最初に書いた ような完全な“はしご”状構透であれば,この此の值は ちょうど 2 になるはずで女る。ST-146-2 の試料の分子 量をジオキサン溶夜の氷点降下から测定したところ, 4900 であった。重合の際, PGE は PDA の 10 倍量を

表 4 PDA-PGE 共重合体の組成

加水分解の条件: $\mathrm{NaOH} 11.55 \times 10^{-3} \mathrm{~mol} / \mathrm{H}_{2} \mathrm{O} 40 \mathrm{ml}, 100$ C で 60 封间 加熱, フェノールフタレインを指示为化して壏酸で滴定

\begin{tabular}{|c|c|c|c|c|c|}
\hline \multirow[b]{2}{*}{ 試料番号 } & \multirow{2}{*}{$\begin{array}{l}\text { 試 料 } \\
\text { 桎限䉼度 } \\
(\mathrm{d} d / \mathrm{g})\end{array}$} & \multirow[b]{2}{*}{ 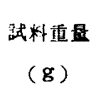 } & \multicolumn{3}{|c|}{ 基更令体租战 } \\
\hline & & & $\underset{(\mathrm{mol} \%)}{\mathrm{PDA}}$ & $\begin{array}{c}\mathrm{PGE} \\
(\mathrm{mol} \%)\end{array}$ & $\begin{array}{l}\mathrm{PGE} \\
\mathrm{PDA} \\
\text { モルH }\end{array}$ \\
\hline & 0.059 & 0.386 & 27.4 & 72.6 & 2.64 \\
\hline ST-151-5 & 0.082 & 0.384 & 31.8 & 68.2 & 2.15 \\
\hline-6\{ & $\begin{array}{l}0.050 \\
0.080\end{array}$ & $\begin{array}{l}0.260 \\
0.401\end{array}$ & $\begin{array}{l}21.6 \\
26.0\end{array}$ & $\begin{array}{l}78.4 \\
74.0\end{array}$ & $\begin{array}{l}3.63 \\
2.84\end{array}$ \\
\hline
\end{tabular}

仕込んでいるため，末端は PGE ユニットである確彎が非常に大 きい。そこで四つの末端ユニットをすべて PGE と考觉る(下困)

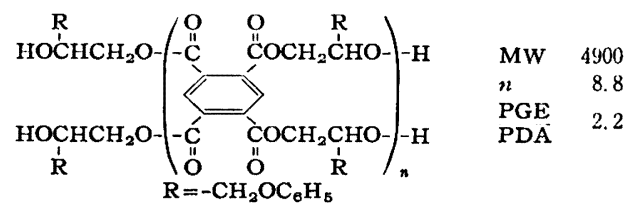

と,“はしごは 8.8 段となるが, PGE とPDA のモル此は 2.2 で，実測值（2.64）はこれよりもまだ大きい。すなおち，末端基 を考慮しても，まだそれ以上に PGE ユニットが多く存在してい ることになる。ST-151-5 では，試料をべンゼンで分別し，その 可溶部と不溶部についてそれぞれ分析した。PGE のホモポリマ 一は，ヘンゼンに可溶であり，もし PGE ユニットの連続がコポ リマー中に存在するなら可溶部の PGE/PDA モル比は不溶部よ りも大きいものと予想される。実測値は可溶部が 3.63 , 不溶部 が 2.84 で，いずれも 2 上りずい分大きく，不溶部は可溶部にく らべて非常に大きい。PGE が連続した部分が存在することはこ れからも想像される。

さらに PGE が DMBA-酸無水物系の触媒で重合する かどうかを確かめた。すなわた，PGE (0.070 mol) をジ オキサン $(80 \mathrm{ml}$ ) 中で, DMBA (刘 PGE $0.02 \mathrm{~mol} \%$ ) 一無水フタル酸（刘 PGE 0.2 mol\%) 系を触媒とし 100 ${ }^{\circ} \mathrm{C}$ で 300 時間加熱すると， $0.12 \mathrm{~g}$ のメタノールに不溶 性のポリマーが得られた。この収量は，PGE が共触媒 として用いた無水フタル酸と羿而共重分の好した場命の 理論収量の 3 倍に相当し，IR スペクトルからも無水フ タル酸の $>\mathrm{C}=\mathrm{O}$ 基の吸収は非常に小さく，エーテル結 
合の吸収が強かっだ。

次に前記 ST-146-2 の試料の末端 $\mathrm{OH}$ 基および $\mathrm{COOH}$ 基の定量を行ない, こ れより計算した分子量と, 氷点降下法に よるそれとを比較した。OH 基はピリジ ンー無水䣫酸によりアセチル化した試料 と、アセチル化していない試料とを、そ れぞれアルカリケン化し，そのアルカリ 消費量の差より求め, $\mathrm{COOH}$ 基は, 直接 アルカリで滴定して求めた。試料はいず れもジオキサンの均一溶液として用い た。

結果は表 5 に示したが, 陚料ポリマー が“はしご”状構造をもつならば， 1 高 分子当り四つの末端基をもつはずで，こ れに基いて計算した分子量は 4600 であり，一方氷点降下法では 前述したように 4900 であった。この二つの值はかなりよく一致 しているものとみられ, このポリマーは予想したような“はしご” 状構造をほぼ满足しているものと思われる。しかし末端基法によ る分子量が, 氷点降下法による分子量よりも小さい值であるのは, 1 高分子に四つ以上の末端基をるつポリマーも存在している可能 性があり，一部には“はしご”の切れたような部分もないとはい 它ない。

表 5 PDA-PGE 共重合体（ST-146-2）の末端基定量 と分子量

\begin{tabular}{|c|c|c|c|c|c|}
\hline 末 端 基 & 試 & $\begin{array}{c}\text { 試料重量 } \\
\text { ( } \mathrm{g} \text { ) }\end{array}$ & $\begin{array}{l}\text { a)ヶン化または } \\
\text { b)中和とるる } \\
\text { ルカリ消費量 } \\
\left(10^{-3} \mathrm{~mol}\right)\end{array}$ & $\begin{array}{l}\text { 試料 } 1 \mathbf{g} \text { 当り } \\
\text { のアルカリ消 } \\
\text { 費暴 } \\
\left(10^{-3} \mathrm{~mol} / \mathrm{g}\right)\end{array}$ & $\begin{array}{l}\text { 术端基含有 } \\
\left(10^{-3} \mathrm{~mol} / \mathrm{g}\right.\end{array}$ \\
\hline $\mathrm{OH}$ & $\left\{\begin{array}{l}\text { アセテル化後 } \\
\text { アセチル化泫 }\end{array}\right.$ & $\begin{array}{l}0.4168 \\
0.2874\end{array}$ & $\begin{array}{l}\text { a) } 3.064 \\
\text { a) } 1.870\end{array}$ & $\begin{array}{l}\text { 7. } 36 \\
6.50\end{array}$ & 0.86 \\
\hline $\mathrm{COOH}$ & アセチル化渞 & 0.4223 & b) 0.005 & 0.012 & 0.012 \\
\hline $\begin{array}{c}\text { 全末端基 } \\
\text { 分子 }\end{array}$ & 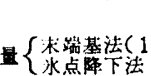 & $T$ & $\tau)$ & & 0.872 \\
\hline
\end{tabular}

以上の契験事実から，この共重合体の構造は，大部分が先に示 したような“はしご”状であるけれども，部分的には PGE ュニ ットの連続した部分，また極く少量ではあるが“はしご”の切れ た部分があると思われる。しかし，この PGE ユニットの連続し た部分というものが，酸無水物を共触媒としてできたホモポリマ 一に近いるのであるのか, あるいは“はしご”の中に化学的に結 合して“はしご”構造が乱れているのか，その区別は明確ではな W。

3.1.6 各種触媒による PDA-PGE 共重合この共重合を DMBA 以外の触媒で試みたが，いずれも好ましい結果は得られ なかった。すなわち，塩化りチウム，トリエチルアルミニウムを 用いると全く重合しないし、ジェチル亜鉛では，重合はするが収 率は悪く(3\%)，得られたポリマーはすべて不溶性であった。ア ルミニウムイソプロポオキシドでは，収率 $33 \%$ で，そのうち 45\% が可溶性のポリマーであった。

\section{$3 \cdot 2$ PDA-ECH 共重合}

3 員環エーテルとして ECH を用いたときの結果を表 6 に示し た。

PGE の場合と问様に，ジオキサン溶媒中で DMBA を触媒に した場合がよく，酢酸ナトリウム，塩化リチウムは触媒として有 効でない。また溶媒として
表 6 PDA-ECH 共重合

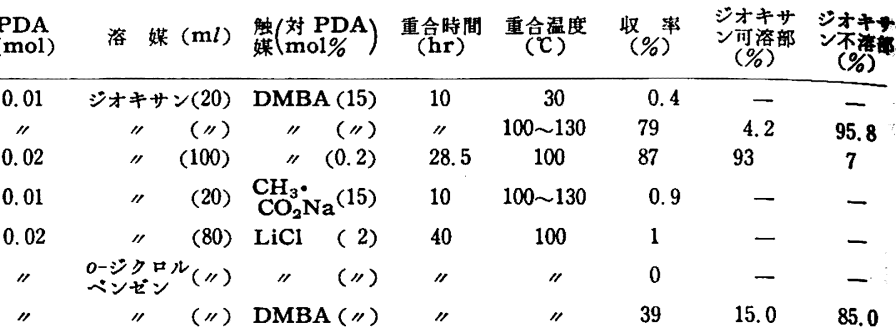

脿 7 PDA-EO 共重合

重合条件: PDA $0.007 \mathrm{~mol}$, DMBA 対 PDA $0.2 \mathrm{~mol} \%$

\begin{tabular}{|c|c|c|c|c|c|c|c|}
\hline EO & $\begin{array}{l}\text { ジオキサ } \\
\text { シ } \\
(\mathbf{m} l)\end{array}$ & $\begin{array}{c}\text { 重合時間 } \\
\text { (hr) }\end{array}$ & $\begin{array}{c}\text { 重合溫度 } \\
\left({ }^{\circ} \mathrm{C}\right)\end{array}$ & $\begin{array}{l}\text { 収 率 } \\
(\%)\end{array}$ & $\begin{array}{c}\text { ジオキサ } \\
\text { ン可溶部 } \\
(\%)\end{array}$ & $\begin{array}{c}\text { ジオキサ } \\
\text { シ不溶部 } \\
(\%)\end{array}$ & 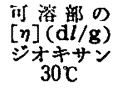 \\
\hline (込み) & 130 & 23 & 100 & 38 & 78 & 22 & 0.4 \\
\hline ") ) & 150 & 33 & 100 & 52 & 35 & 65 & 0.14 \\
\hline （逻流） & 80 & 21.5 & 95 & 92 & 6 & 94 & - \\
\hline
\end{tabular}

DMBA 触媒でも，不溶性ポリマーの方が多くなる。ジオキサン -DMBA の系でも PDA の濃度が高いとほとんどがゲル化してし まった。

\section{3 .3 PDA-EO 共重合}

3 員環エーテルとして EO を用いたときの結果を表 7 に示し た。

PDA と EO を混合して還流する方法では，收涪はよいがほと んどがゲル化してしまうのに対し，EOを重合系中へ吹込む方法 では, 可溶部が比較的多く得られる。ST-157-1 は ST-156 の場 合にくらべて, PDAの濃度は低く, EO の欣込み速度も扣そかっ たにもかかわらず，ゲル化したポリマーが多かった。PGE の場合 とはちがって，モノマーの濃度よりも重合時間の方が影響が大き いようである。ST-157-1 のジオキサン可溶部の X線回折写真に は非常に弱いけれどす，結晶性を示寸環がみられた。同じ試料を 加水分解によって EO/PDA モル比を求めると， 2.98 と非常に大 きかった。したがって，この場合にもEOの連続したものがコポ リマー中に，またはホモポリマーとして存在する可能性もあるが, EO のホモポリマーはメタノールに可溶であり，一応除かれてい ると考えられるから，この場合にはポリ EO がコポリマーに結合 しているものと思われる。EO/PDAのモル比は，末端ニニットを 考慮すれば完全な“はしご”構造の場合の 2 からのずれは，X線 的に結晶性を示すほどに長いポリEO の鎖が存在するとは考えに くく，“はしご”状の構造で固換基が全くないために， X 線的に 弱い結晶性を示したものと考えられる。

\section{$3 \cdot 4$ PDA-BCMO 共重合}

4 員環エーテルとして BCMO を用い, トリクロル酢酸ナト リウム, フタル酸ナトリウム, 塩化リチウムを触媒として, 重合

表 8 PDA-BCMO 共重合

重合策作: PDA $0.01 \mathrm{~mol}$, BCMO $0.02 \mathrm{~mol}$ ，能媒刘 PDA $0.5 \mathrm{~mol} \%$, ジオキサン $30 \mathrm{~m} l$, 重合時閌 $3 \mathrm{hr}$

\begin{tabular}{|c|c|c|c|c|c|c|c|c|}
\hline \multirow[b]{2}{*}{ 火帾番㕫 } & \multirow[b]{2}{*}{ 触 } & \multirow[b]{2}{*}{ 媒 } & \multirow{2}{*}{$\begin{array}{c}\text { 重 } \\
\text { 温 度 } \\
\text { (C) }\end{array}$} & \multirow[b]{2}{*}{$\begin{array}{l}\text { 収 革 } \\
\text { (\%) }\end{array}$} & \multirow{2}{*}{ 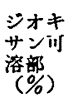 } & \multirow[b]{2}{*}{$\begin{array}{c}\text { 间 } \\
\text { 不溶部 } \\
(\%)\end{array}$} & \multicolumn{2}{|c|}{ ジオキサン可溶㰾 } \\
\hline & & & & & & & 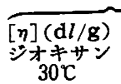 & $\frac{\mathrm{BCMO}^{\mathrm{BCMA}}}{\text { モル比 }}$ \\
\hline $\mathbf{T}-173$ & \multicolumn{2}{|c|}{$\mathrm{CCl}_{3} \mathrm{CO}_{2} \mathrm{Na}$} & 100 & 0 & - & - & - & - \\
\hline $\begin{array}{l}-1 \\
-2\end{array}$ & \multirow{2}{*}{\multicolumn{2}{|c|}{${ }^{\left.o-\mathrm{C}_{6}, \mathrm{H}_{4} \cdot{ }^{\prime} \mathrm{Na}\right)_{0}}$}} & 150 & 0 & - & - & - & - \\
\hline-3 & & & 100 & 0 & - & - & - & - \\
\hline-4 & & 15 & 74 & 100 & 0 & 0.14 & 1.94 \\
\hline-5 & \multicolumn{2}{|l|}{$\mathrm{LiCl}$} & 10 & 0 & - & - & - & - \\
\hline-6 & 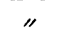 & & 150 & $\sim 100$ & 76 & 24 & 0.20 & 1.49 \\
\hline
\end{tabular}


沮度を 100 または $150^{\circ} \mathrm{C}$ の場合についてしらべた。結 果を表 8 に示した。

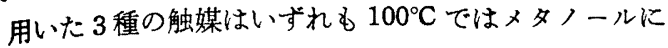
不溶の生成物は与えず,すべて淡黄色の油状ポリマーで ある。重合温度を $150^{\circ} \mathrm{C}$ にすると、フタル酸ナトリウ ム，または塩化りチウムを触媒にした場合には、メタノ 一ルに不溶の粉末を与える。特に前者を触媒にした場合 は，100\% がジオキサンに溶ける白色の粉末である。加 水分解による $\mathrm{BCMO} / \mathrm{PDA}$ モル比は，いずれも2より小 さく,PGEの場合とちがって酸無水物基がすべて重合に

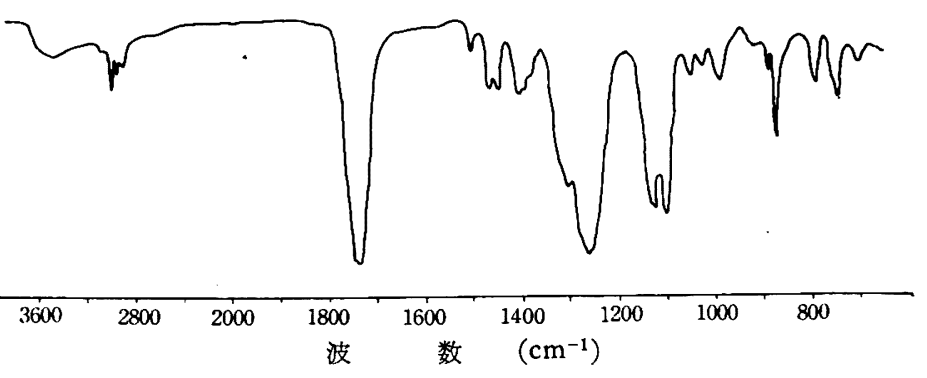

図 3 PDA-BCMO 共重合体の赤外吸収スペクトル

値から,この試料は, ある程度の高分子量体であろ PDA-PGE 共重合体の場合を考它合わすと， $\mathrm{OH}$ 基の吸収がみら れることは，1高分子当り，四つ以上の末端基がある可能性を示 している。従って, 前述したように, PDA-BCMO 共重合では, PDA の酸無水物基はすべてが “はしご”状構造に関与せず，一 部には“はしご”の切れたものがあり，またェーテル結合の吸収 のみられることから， BCMO の連続した部分も存在し，PDAPGE の場合とちがい“はしご”の乱れはかなり大きいようであ る。

（本報の一部は昭和 39 年 4 月，日本化学会第 17 年会(東京) で発表した）

\section{ピペラジン環を含むポリアミドおよびポリ尿素の合成†}

（昭 和 40 作 4 月 30 日 受理)

\section{須 本 操 磯 崎 哲 正*}

高分子原料としてピペラシンを利用し，しかも溶解性に富み，高結晶性，高融点の高分子化合物をつくる目的で，ピぺ ラジン罍を含む各種二塩基酸エステルを合成し，それとジアミン類とを反応させることによって，ホリアミドおよびポ 尿奖を合成した。

反忍はプレポリマーを合成する第 1 段階と，高重籍合体を合成する第 2 段階とに分けて行ない，溶媒，触媒の存在する 诏合についても研究した。

得られたポリアミドの多くは, メタノール, エタノール等のフルコール類, 四塩化ェタン, 酢酸扣よび水（酸性）に溶

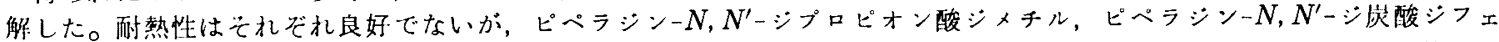
ニル等は各種ジミンと反応して，容易に高融点，高結晶性のポリアミド拈よびポリ尿素を与学た。ポリアミトに比べポ リ沗素の方は，溶解吽は少るが，耐熱性はまさった。

\section{1 腥言}

ピペラジンは飽和 6 員環構造を有する比較的安価な第 2 級ジア ミンであって，エチレンジアミンの接触脱アミノ化またはエチレ ンクロリドとアンモニアの反応によって製造され, 現在, 医薬品 等として若干使用されているものである。

従来から，ピペラジンそのものをジアミン成分とする高分子化 命物の合成は，多数試みられている。たとえば,脂肪族二塩基酸と の重䈤合によるポリアミドの合成 ${ }^{1)}$, 界面重縮合法によるポリア ミドの合成2)，ポリウレタンの合成 ${ }^{3)}$ およびポり尿素の合成 ${ }^{4)}$, ジ

†本研究には，著者が大阪工業技術試験所在職中に行なった 部分的含む。

* Misao SUmoto, Tesshyo ISOZAKI 坴羽紡績株式会社高 柣研觉所：高梘市西天川。
イソシアナートを用いるポリ尿素の倠成等5)，その他多数の特阡

1) T. Lieser et al., Ann. 556, 114 (1944); D. D. Coffmann J. Polymer Sci. 2, 306 (1947) ; R. D. Evans et al., J. Am. Chem. Soc. 72, 2018 (1950) ; W. J. Peppel, J. Polymer Soc. 51，64 (1961); 長谷川, 綿織, 岡太, 工化 65 , 661 (1962).

2) R. G. Beaman et al., J. Polymer Sci. 40, 329 (1959); M. Katz, ibid. 40, 337 (1959) ; C. W. Stephens, ibid. 40, 359 (1959) ; M. L. Wittbecker, M. Katz, ibid. 40, 367 (1959) ; D. J. Lyman, S. L. Jung, ibid. 40, 405 (1959) ; 庄野 5, 工化 65, 658 (1962) ; P. W. Morgan \& S. L. Kwolek, J. Polymer Sci. A 2, 181, 209, 2693, 5149 (1964).

3) Chem. Eng. News 41, 41 (1963).

4) D. J. Lyman et al., J. Polymer Sci. 40, 407 (1959).

5) A. A. Strepikheev et al., Chem. Abst. 49, 6122 (1955). 